\title{
OPTIMALISASI NILAI-NILAI FITRAH DALAM MENDEKATKAN DIRI KEPADA ALLAH
}

\author{
Andi Nurlaela ${ }^{1}$, Su'udyah Ningrum $^{2}, \mathrm{Naan}^{3}$ \\ UIN Sunan Gunung Djati Bandung \\ J1. AH. Nasution No. 105, Bandung Jawa Barat Indonesia \\ E-mail : nurlelalandi@uinsgd.ac.id ${ }^{1}, \underline{\text { dyahningrum088@gmail.com }}{ }^{2}$ \\ naan@uinsgd.ac.id ${ }^{3}$
}

\begin{abstract}
Abstrak
Fitrah merupakan hakikat dasar yang dimiliki oleh setiap manusia. Dalam hal ini fitrah bersifat baik, karena manusia dilahirkan dalam keadaan suci. Fitrah berhubungan dengan Hanif, yakni sifat manusia yang selalu merindukan dan mencari kebenaran. Fitrah merupakan sebuah potensi dasar dalam kehidupan manusia. Penelitian ini bertujuan untuk mengaplikasikan fitrah manusia sebagai potensi dalam mendekatkan diri kepada Allah. Topik tentang fitrah dipilih karena dibutuhkan dunia akademisi, terutama menjadi kajian pokok beberapa mata kuliah pada jurusan Tasawuf dan Psikoterapi. Penelitian in menggunakan pendekatan kualitatif. Literatur berupa buku-buku dan artikel jurnal yang membahas tentang fitrah atau yang beririsan dengan tulisan artikel ini menjadi sumber data. Data-data yang diperoleh kemudian diolah dan dianalisis sesuai dengan kebutuhan penelitian. Hasil penelitian menunjukkan bahwa Fitrah adalah potensi yang dimiliki manusia, mengandung sifat hanif yang memungkinkan manusia berjalan menuju Allah. Fitrah juga menjadi bagian dari bentuk penyerahan diri. Kefitrahan manusia dapat benar-benar muncul ke permukaan dirinya ketika secara tulus dapat menjalankan rukun Islam yang lima tersebut.
\end{abstract}

Kata Kunci: Fitrah, Manusia, Islam

\section{Abstract}

Fitrah is the basic essence of every human being. In this case nature is good, because humans are born in a holy state. Fitrah is related to Hanif, namely human nature who always longs for and searches for the truth. Fitrah is a basic potential in human life. This study aims to apply human nature as a potential in getting closer to Allah. The topic of fitrah was chosen because it was needed by the academic world, especially as the main study of several courses in the Sufism and Psychotherapy majors. This research uses a qualitative approach. Literature in the form of books and journal articles that discuss fitrah or that intersect with the writing of this article is a source of data. The data obtained were then processed and analyzed according to the research needs. The results showed that Fitrah is a human potential, containing hanif traits that allow humans to walk towards Allah. Fitrah is also a part of submission. Human slander can really come to the surface when he can sincerely practice the five pillars of Islam

Keywords:, Fitrah, Human, Islam

Al Qalam: Jurnal Ilmiah Keagamaan dan Kemasyarakatan

Vol. 14, No. 2, Juli-Desember 2020 
Andi Nurlaela, Su'udiyah Ningrum, Naan : Optimalisasi Nilai-Nilai Fitrah Dalam Mendekatkan Diri Kepada Allah

\section{PENDAHULUAN}

Manusia merupakan makhluk Allah yang paling sempurna. Manusia dianugerahi akal untuk bekal pada proses kehidupannya. Ia mampu membedakan antara kebaikan dan keburukan. Kemampuan ini secara potensial telah ada pada diri manusia. ${ }^{1}$ Bagi manusia sendiri ketika mereka ditanya tentang definisi manusia, banyak dari mereka yang kurang bisa dalam menjawab secara padat. Kebanyakan dari mereka mendefinisikan diri mereka dengan satu dua kata singkat, seperti manusia adalah makhluk Allah yang sempurna, hayawanun naatiq, homo sapien, homo education, rational animal, dan sebagainya.

Tujuan diciptakannya manusia oleh Allah tidak lain hanya agar mereka beribadah dan menyembah-Nya. Manusia diciptakan juga sebagai khalifatul fil ardhi (sebagai penguasa di bumi). Awal ketika manusia setelah diciptakan, dalam hal ini adalah penciptaan Adam, Allah menunjukkan betapa istimewanya manusia yang sudah diciptakan-Nya dengan menyuruh para malaikat dan jin untuk bersujud kepada manusia, namun karena kesombongannya, jin tidak mau bersujud kepada manusia.

Ketika penciptaan manusia, Allah anugerahkan kepada mereka sebuah potensi baik dalam dirinya, potensi ini sering disebut dengan istilah fitrah. Fitrah ini merupakan potensi yang mendasar pada manusia, karena sebelum manusia mengetahui apapun di dunia, ia sudah mempunyai fitrah sebagai bekal kehidupan. Fitrah ini bersifat suci dan selalu mengarah kepada kebaikan dan kebenaran. Adapun fitrah manusia selalu bersifat hanif, artinya fitrah secara alami selalu mencari dan merindukan segala yang benar dan yang baik.

Pada zaman Rasulullah SAW., fitrah disebutkan sebagai suatu keadaan manusia yang ketika dilahirkan dalam kadaan suci. Sesuai dengan hadits Nabi SAW yang artinya, "Setiap manusia yang lahir dilahirkan dalam keadaan fitrah (suci)." (HR. BukhariMuslim)

Dalam hadits tersebut timbullah pertanyaan, apakah fitrah itu kesucian tanpa dosa atau Islam sebagai agama? Bagi mereka yang mengartikan bahwa fitrah itu agama Islam, maka ada tambahan matan pada hadits tersebut “..Dan orangtuanyalah yang menjadikan dia seorang Yahudi atau Nasrani ataupun Majusi”. Sedangkan pendapat lain terutama

${ }^{1}$ Syarifah Ismail, Tinjauan Filosofis Pengembangan Fitrah Manusia dalam Pendidikan Islam, Jurnal At-Ta'dib Vol. 8, No. 2, Desember 2013

Al Qalam: Jurnal Ilmiah Keagamaan dan Kemasyarakatan Vol. 14, No. 2, Juli-Desember 2020 
Andi Nurlaela, Su'udiyah Ningrum, Naan : Optimalisasi Nilai-Nilai Fitrah Dalam Mendekatkan Diri Kepada Allah

yang berkembang di kalangan Sufi, fitrah merupakan keadaan manusia yang suci, fitrah tidak memaksa manusia masuk ke dalam agama Islam. Karena ketika manusia dilahirkan ia tidak mengetahui apapun. Sehingga Allah memberinya penglihatan, pendengaran, dan hati agar ia bersyukur ${ }^{2}$. Dalam hal ini bisa disimpulkan tanpa faktor lingkungan pun, fitrah akan dengan sendirinya menuntun manusia ke dalam kebenaran dan kebenaran itu mutlak ada pada agama Islam. Hal ini disebabkan karena fitrah sendiri mempunyai potensi akan tauhid. Perdebatan mengenai pemaknaan fitrah ini hingga sebelum abad ke 3 Hijriyah/9 Masehi tidak bisa ditemukan titik terangnya.

Penelitian dengan tema fitrah yang dilakukan merupakan dimensi lain dari penelitian tema sejenis sebelumnya. Yang membedakan adalah orientasi kajiannya. Berikut ini beberapa ulasan hasil penelitian dengan tema fitrah yang telah dipublish pada jurnal online, di antaranya:

Muliya Rahayu ${ }^{3}$ menulis artikel dengan judul Konsep Fitrah Manusia Dalam AlQur'an Dan Implikasinya Dalam Pendidikan Anak Usia Dini. Tulisan ini membahas tentang Fitrah manusia yang tertulis dalam Al-Qur'an yang berdampak pada pendidikan anak pada usia dini. Dikatakannya, secara fitrah Allah menciptakan manusia dengan sempurna. Tujuan penciptaan manusia untuk beribadah dan mentaati peraturan-Nya. Dengan demikian, manusia sebagai khalifah di bumi dapat diwujudkan. Dimensi fisik, jiwa dan ruh merupakan aspek Fitrah manusia. Daya cipta manusia muncul dan terbentuk dari aspek fitrah manusia tadi. Daya cipta, rasa dan karsa manusia, sangat mungkin dapat mengembangkan seluruh potensi-potensi yang ada padanya demi terciptanya kemaslahatan penduduk bumi dan alam raya. Kembalinya manusia kepada konsep fitrah yang termaktub dalam Al-Qur'an dapat memberi jalan penerang hidupnya dan menjadi makhluk yang beradab dan berjiwa pemimpin bumi. Fitrah munusia ini dapat dipupuk sejak usia dini, bahkan sejak manusia ada dalam kandungan ibunya. Orangtua memberi peran penting dalam pendidikan dasar ini. sementara sekolah, mengikuti irama pendidikan keluarga, demi optimalisasi fitrah anak.

${ }^{2}$ Mappanganro M , Mengembangkan Pendidikan Yang Menghargai Nilai Dan Fitrah Manusia, EDUKASI Jurnal Penelitian Pendidikan Agama dan Keagamaan Volume 1, Nomor 4, Oktober 2003

${ }^{3}$ Muliya Rahayu, Konsep Fitrah Manusia Dalam Al-Qur'an Dan Implikasinya Dalam Pendidikan Anak Usia Dini. Jurnal Pusaka : Media Kajian dan Pemikiran Islam, Vol. 4 No. 1 (2016)

Al Qalam: Jurnal Ilmiah Keagamaan dan Kemasyarakatan Vol. 14, No. 2, Juli-Desember 2020 
Andi Nurlaela, Su'udiyah Ningrum, Naan : Optimalisasi Nilai-Nilai Fitrah Dalam Mendekatkan Diri Kepada Allah

Mualimin ${ }^{4}$ menulis pentingnya implikasi fitrah manusia bagi pendidikan Islam. konsep fitrah ini dapat menjadi landasan yang kuat bagi dunia pendidikan Islam. Tulisan ini tidak terlalu jauh berbeda dengan tulisan Muliya Rahayu. Perbedaannya pada fokus penelitian, yang satu terbatas pada konsep pendidikan, sementara yang lainnya lebih spesifik lagi, pada pendidikan usia dini.

Uul Nur Janah, ${ }^{5}$ mengupas konsep fitrah manusia yang erat hubungannya dengan kreativitas yang dimiliki anak. Sebagai potensi yang dibawa sejak lahir. Fitrah perlu mendapatkan perhatian untuk dikembangkan. Optimalisasi potensi anak dalam Islam, dapat dilakukan melalui pendidikan. Pendidikan Islam dapat membantu menjaga kefitrahan manusia, karena di dalamnya terdapat pendidikan manusia secara utuh. Pendidikan Islam sendiri berpijak pada fitrah, yakni potensi yang ada pada manusia. Dengan kata lain, pendidikan Islam berorientasi pada fitrah, dari dan untuk fitrah.

Toni Pransiska, ${ }^{6}$ menyatakan bahwa salah satu konsep penting dalam pendidikan Islam adalah konsep fitrah. Konsep fitrah tidak identik dengan Teori Empirisme (teori tabularasa). Oleh karena itu, teori Empirisme - yang dikemukakan oleh John Locke memandang bahwa orang berkulit putih, seperti kertas belum dicoret. Lingkungan dan pendidikanlah yang memberi warna pada kertas. Sebaliknya pandangan bahwa fitrah manusia lebih dari sekedar kertas putih dan bersih, tetapi di alam ada potensi yang diemban oleh manusia. Potensi itu adalah kekuatan atau kekuatan untuk menerima agama atau tauhid. Oleh karena itu, lingkungan dan pendidikan memiliki peran strategis dalam mengembangkan sifat manusia, akhirnya alam yang terpelajar menjadikannya sebagai generasi masyarakat yang cinta damai, inklusif dan perbaikan yang berkelanjutan.

Sementara Muhammad $\mathrm{Miftah}^{7}$, berpendapat bahwa potensi insaniah atau bakat bawaan adalah fitrah manusia. Itulah konsep Islam tentang fitrah manusia. Lahirnya manusia ke dunia ini bukanlah ibarat kertas kosong yang siap dituliskan sesuatu padanya.

${ }^{4}$ Mualimin, Konsep Fitrah Manusia Dan Implikasinya Dalam Pendidikan Islam AlTadzkiyyah: Jurnal Pendidikan Islam, Vol 8, No 2 (2017)

${ }^{5}$ Uul nur janah, Konsep Fitrah Manusia dan Relevansinya Terhadap Pengembangan Kreativitas Anak dalam Pendidikan Islam, Golden Age, Jurnal Ilmiah Tumbuh Kembang Anak Usia Dini, Vol 2 No 1 (2017)

${ }^{6}$ Toni Pransiska, Konsepsi Fitrah Manusia Dalam Perspektif Islam Dan Implikasinya Dalam Pendidikan Islam Ontemporer, Jurnal Ilmiah Didaktika Media Ilmiah Pendidikan dan Pengajaran Vol 17, No 1 (2016)

7 Muhammad Miftah, Quantum Learning Dan Fitrah Manusia Dalam Perspektif Pendidikan Islam, Insania, Vol. 25, No. 1, Januari - Juni 2020

Al Qalam: Jurnal Ilmiah Keagamaan dan Kemasyarakatan

Vol. 14, No. 2, Juli-Desember 2020 
Andi Nurlaela, Su'udiyah Ningrum, Naan : Optimalisasi Nilai-Nilai Fitrah Dalam Mendekatkan Diri Kepada Allah

Sebaliknya, memiliki frame atau latar yang kuat berupa potensi bawaan. Potensi unik dan berbeda dengan individu lain merupakan potensi yang unik. Perbedaan potensi inilah sebagai salah satu potensi alamiah tiap individu. Kelemaha dan kelebihan melekat pada potensi ini. tugas individu lah berupaya melakukan optimalisasi fitrah dengan caranya masing masing dan mengarahkan pada perilaku baik di masyarakat dan ketaatan kepada Allah. Model pembelajaran Quantum learning adalah model pembelajaran praksis yang dapat memadukan keunikan-keunikan individu yang dimilikinya. Seluruh potensi individu dapat melesat tanpa mengabaikan dan menekan keunikan dan perbedaan potensi tiap peserta didik. Id, ego dan superego adalah teori Sigmund Freud yang dapat dijadikan sebagai pendekatan demi melejitkan potensi peserta didik. Quantum learning dapat menyelaraskan id, ego dan superego yang memungkinkan melahirkan kenyamandan dan kebahagiaan bagi peserta didik. Proses pembelajaranpun menjadi menyenangkan.

Suriadi $^{8}$, menyebutkan Agama Islam sebagai agama fitrah tidak hanya sesuai dengan naluri religiusitas manusia, tetapi juga sesuai dengan perkembangan fitrahnya, termasuk sumber-sumber manusia yang akan membawa kepada keutuhan dan kesempurnaan pribadinya. Kesempurnaan pribadi inilah yang dalam pendidikan Islam disebut sebagai Insan Kamil, atau manusia sempurna. Secara alamiah, manusia telah menemukan tauhid, meski masih di alam non-materi (alam roh). Dari pengertian tersebut dapat dipahami bahwa fitrah manusia adalah kecenderungan untuk mengetahui, atau mencari Tuhan. Ini bisa ditemukan dalam konsensus antara Tuhan dan roh yang kemudian menjadi konstitusi umum. Konsensus dimulai dengan pertanyaan Tuhan kepada roh, bukankah aku Tuhanmu? (mereka menjawab) pasti Anda tuhan kami, kami adalah saksi. Manusia adalah makhluk karena dipengaruhi oleh bawaan (potensi dasar manusia) dan lingkungan. Ini adalah salah satu hakikat manusia.

\section{METODE PENELITIAN}

Dalam kesempatan penelitian ini, penulis melakukan studi analisis referensi yakni penelitian yang dilakukan untuk mencapai suatu pemahaman tentang bagaimana masalah bisa menjadi sebuah pendangan yang konkret sesuai tujuan yang diinginkan. Jenis metode yang digunakan penulis adalah content analysis (analisis isi) yakni dengan menganalisis

${ }^{8}$ Suriadi, Fitrah Dalam Perspektif Al-Quran (Kajian Terhadap Ayat-Ayat Al-Quran), MUADDIB: Studi Kependidikan dan Keislaman Vol. 8 No. 2 (2018)

Al Qalam: Jurnal Ilmiah Keagamaan dan Kemasyarakatan

Vol. 14, No. 2, Juli-Desember 2020 
Andi Nurlaela, Su'udiyah Ningrum, Naan : Optimalisasi Nilai-Nilai Fitrah Dalam Mendekatkan Diri Kepada Allah

berbagai data referensi sehingga data penelitian yang dibutuhkan bisa tercapai. Sifat dari penelitian ini adalah formalitas akademik, dengan strategi peningkatan penguatan akademik serta kajian literasi dalam konsentrasi di bidang kajian Tasawuf dan Psikoterapi.

Buku-buku yang berisikan materi fitrah menjadi rujukan utama. Namun demikian, sesuai dengan kebutuhan penulisan artikel jurnal. Maka, rujukan topik fitrah diperluas dengan menggunakan artikel jurnal yang berisikan pembahasan tentang fitrah.

Artikel jurnal dengan tema fitrah yang telah dipublikasikan ini dijadikan rujukan pendamping dan dasar bagi penelitian ini. perlu disebutkan di sini, bahwa penelitian fitrah ini tidak berdiri sendiri, namun beririsan dengan penelitian sebelumnya yang membahas tentang fitrah. letak perbedaan penelitian ini dengan penelitian lainnya terletak pada fokus kajian salah satu variabelnya. Untuk itulah, artikel jurnal tentang fitrah menjadi data penting untuk dikumpulkan dan diolah dan di rangkai menjadi satu kesatuan yang utuh.

Data yang terkumpul kemudian dipilah-pilah dan dikategorisasi. Setelah itu, tiap data diberi makna sesuai dengan kebutuhan penulisan. Tidak semua data digunakan pada penelitian ini. data yang dipakai adalah data yang sesuai dengan kebutuhan penelitian tentang fitrah dalam upaya mendekatkan diri kepada Allah. Untuk itu, data yang tidak dibutuhkan dipisahkan. Data-data yang terpakai ini kemudian disusun berdasarkan struktur penelitian yang telah ditentukan.

\section{HASIL DAN PEMBAHASAN}

Secara harfiah, fitrah akar katanya adalah "fatara" yang berarti cipta (penciptaan dan menciptakan, kemudian menjadi bentuk masdar "fitrah" yang bermakna ciptaan atau sifat dasar yang telah ada saat diciptakannya. Menurut hemat penulis, fitrah disebut sebagai sifat dasar yang telah ada saat diciptakan adalah karena Allah menganugerahkan fitrah ketika manusia berada di alam immateri (alam roh), ketika terjadi perjanjian antara manusia dengan Allah, sesuai dengan yang termaktub dalam surat Al-A'raf ayat 172. Dalam kamus besar bahasa Arab al-Munjid, fitrah disebutkan sebagai Penciptaan sifat yang mensifati semua yang hidup di saat penciptaan ${ }^{9}$. Secara sederhana fitrah dapat diartikan sebagai sifat asal, kesucian, bakat, pembawaan. Kamus Indonesia-Inggris yang

\footnotetext{
1975)

${ }^{9}$ Louis Ma'luf, Al-Munjid Fi Al-Luhgah Wa Al-A'lam (Bairut-Libanon, Dar el-Mashreq,
}

Al Qalam: Jurnal Ilmiah Keagamaan dan Kemasyarakatan

Vol. 14, No. 2, Juli-Desember 2020 
Andi Nurlaela, Su'udiyah Ningrum, Naan : Optimalisasi Nilai-Nilai Fitrah Dalam Mendekatkan Diri Kepada Allah

disusun John Echols dan Hasan Sadili, mengartikan fitrah dengan natural, tendency, disposition, character $^{10}$. Kemudian Abdul Aziz berpendapat bahwa fitrah adalah potensi manusia yang dapat digunakan untuk hidup di dunia. Dengan potensi-potensi itu manusia akan mampu mengantisipasi semua problem kehidupan yang beragam. Ibarat kompas yang selalu menunjukkan arah ketika manusia tersesat ${ }^{11}$.

Kata fitrah telah disebutkan Al-Qur'an sebanyak 20 kali dengan rincian pada 17 surat dan 19 ayat yang mengemuka dalam bentuknya yang beragam ${ }^{12}$. Salah satunya dalam surat Ar-Rum ayat 30, Allah Berfirman:

"Maka hadapkanlah wajahmu dengan lurus kepada agama (Islam); (sesuai) fithrah Allah disebabkan Dia telah Menciptakan manusia menurut (fitrah) itu. Tidak ada perubahan pada Ciptaan Allah. (itulah) agama yang lurus, tetapi kebanyakan manusia tidak mengetahuinya"

Berdasarkan ayat di atas, bisa diketahui bahwasannya fitrah digambarkan memiliki dua dimensi yakni fitrah manusia dan fitrah agama. Kefitrahan manusia berwujud potensi-potensi yang melekat pada dirinya. Sementara fitrah agama berupa wahyu ilahi dan Sunnah Nabi. Sekilas keduanya tidak sama, namun jika kita teliti dalam kandungan maknanya, maka kedua gambaran fitrah itu sama, sama-sama mengajak kepada kebenaran sesuai wahyu dan sunnah. Adapun fitrah agama yang dimaksud ialah manusia yang beragama Islam, karena tujuan manusia diciptakan tidak lain hanya untuk kembali kepada Allah. Disini fitrah bersifat tauhid, selalu kembali dan bergantung kepada Sang Penciptanya. Sedangkan yang dimaksud fitrah manusia ialah dimana karena adanya fitrah itu manusia selalu terbimbing dan terarahkan kepada apapun yang baik dan benar. Karena fitrah di sini juga mengandung sifat ketauhidan, dan tauhid disini ialah sesuatu yang mengarah kepada Sang Pencipta sehingga ia akan selalu berada di jalan yang benar. Dalam "Tafsir Al-Qurthubi", Al-Qurthubi berpendapat bahwa ada kaitan ayat di atas disandarkan pada Hadist Rasul : "Bukanlah Aku telah menceritakan kepadamu tentang sesuatu yang telah dikatakan Allah kepadaku dalam kitab-Nya, bahwa Allah telah menciptakan Adam dan anak cucunya untuk tetap menjadi orang muslim”. Fitrah adalah

${ }^{10}$ Jhon. M Echols and Hasan Shadily, Kamus Indonesia-Inggris (Jakarta Gramedia, 1994)

${ }^{11}$ Toni Pransiska, Konsepsi Fitrah Manusia Dalam Perspektif Islam Dan Implikasinya Dalam Pendidikan Islam Kontemporer, Jurnal Ilmiah Didaktika Media Ilmiah Pendidikan dan Pengajaran Vol 17, No 1 (2016)

12 Risdawati Siregar, Pengembangan Fitrah Manusia Melalui Konseling Islam, FITRAH:Jurnal Ilmu-ilmu Keislaman, Vol 1, No 1 (2015)

Al Qalam: Jurnal Ilmiah Keagamaan dan Kemasyarakatan

Vol. 14, No. 2, Juli-Desember 2020 
Andi Nurlaela, Su'udiyah Ningrum, Naan : Optimalisasi Nilai-Nilai Fitrah Dalam Mendekatkan Diri Kepada Allah

agama yang telah ditetapkan Allah kepada manusia dan tiada sesuatu apapun yang dapat mengubahnya baik faktor endogen maupun eksogen, karena dalam ayat tersebut jelas termaktub "Tiada perubahan apapun dalam penciptaan itu”, maka sangatlah tidak wajar jika ada manusia atau sekelompok orang yang tidak beragama, karena berarti ia telah mengingkari fitrahnya ${ }^{13}$.

Fitrah manusia memiliki kecenderungan dalam mengajak kepada kebenaran, walaupun hanya terucapkan pada hati kecilnya. Adakalanya manusia sudah mempercayai kebenaran yang terbisik dalam hatinya, namun karena faktor eksogen atau lingkungan membuat dia berpaling dari bisikan kebenaran hatinya menuju ajakan eksogen yang terkadang dengan menurutinya membuat ia diterima di kalangan sekitarnya.

Fitrah juga berarti potensi dasar bagi manusia, karena manusia lahir sudah bersama fitrah dan tabiat alami yang dimiliki manusia pada saat penciptaannya cenderung menerima kebenaran. Manusia dilahirkan dengan pembawaan karakteristik yang berbedabeda, jiwa dan hati sanubari merupakan karakter yang bisa membawa individu pada mengenal Allah atau ma'rifatullah. Sayid Quthub dalam Tafsir fi Dzilail Quran menjabarkan makna fitrah berupa jiwa kemanusiaan yang perlu dilengkapi dengan tabiat beragama, antara tabiat beragama dan fitrah kejiwaan merupakan hubungan nan utuh. Keduanya adalah potensi dasar yang diciptakan Allah untuk memberikan hikmah dan mengubah diri ke arah yang lebih baik, meluruskan diri dari-Nya danmengobati sakitnya jiwa.

\section{Fitrah Manusia Sebagai Potensi Dasar}

Fitrah manusia sebagai potensi dasar bermula dari ketika manusia baru dilahirkan. Ketika manusia pertama dilahirkan ia tidak bisa langsung mengetahui seluk beluk dunia. Manusia lahir ibarat kertas putih, ia terlahir suci tanpa ada noda sedikitpun. Manusia dilahirkan dengan dianugerahi panca indera. Dengan panca indera manusia bisa mempelajari dan mengetahui sesuatu.

Dalam kehidupannya, manusia tidak bisa hanya mengandalkan panca indera untuk menjalani kehidupannya sebagai khalifatul fil ardh. Dibutuhkan adanya kontribusi fitrah dalam mencari pengetahuan. Disini lah mengapa fitrah disebut dengan potensi

\footnotetext{
${ }^{13}$ Naila Farah and Cucum Novianti, "Fitrah Dan Perkembangan Jiwa Manusia Dalam Perspektif Al-Gazali” 2 (2016): 189-215
}

Al Qalam: Jurnal Ilmiah Keagamaan dan Kemasyarakatan

Vol. 14, No. 2, Juli-Desember 2020 
Andi Nurlaela, Su'udiyah Ningrum, Naan : Optimalisasi Nilai-Nilai Fitrah Dalam Mendekatkan Diri Kepada Allah

dasar manusia, karena dengan fitrah manusia bisa mengetahui mana yang benar dan yang buruk. Karena sifat fitrah itu sendiri ialah selalu mengarah kepada kebaikan.

Sebagai contoh dalam hal memeluk agama. Dalam ajaran Islam, kita dilarang memaksakan seseorang untuk memeluk ajaran Islam, biarlah ia masuk ke agama Islam dengan dasar keyakinannya sendiri tanpa ada paksaan. Seperti halnya firman Allah dalam surat Al-Baqarah ayat 256:

"Tidak ada paksaan dalam (menganut) agama (Islam), sesungguhnya telah jelas (perbedaan) antara jalan yang benar dengan jalan yang sesat....."

Berdasarkan ayat di atas, diketahui bahwa alasan tidak bolehnya manusia memaksa manusia yang lain dalam menganut agama karena pada dasarnya manusia dianggap sudah mampu memilih mana yang benar dan yang salah. Manusia diberi kebebasan dalam memilih agama yang akan dianutnya. Ia harus mendengarkan hati nya di agama manakah dan kepercayaan serta Tuhan apa yang harus diikutinya. Karena fitrah sejatinya selalu menuju kepada kebenaran, dan sudah ada perjanjian antara manusia dengan Tuhan di alam immateri, maka seyogyanya manusia percaya bahwa ajaran yang harus diantunya adalah ajaran Islam. Karena pada ajaran Islam, manusia menemukan apa dan mengapa dia hidup di dunia. Dalam ajaran Islam pun, manusia memperoleh pemahaman yang mendalam tentang kebaikan dan kebenaran. Adapun efek percaya kepada Tuhan, membuat manusia memperoleh pegangan dan sandaran hidup yang kuat, serta akan membebaskan manusia dari belenggu mitologi sesama manusia dan alam.

\section{Fitrah dan Kehanifan Manusia}

Sifat hanif merupakan kelanjutan dari fitrah manusia yang suci. Kata hanif dalam Al-Qur'an bermakna sikap alami manusia yang selalu memihak kepada yang benar dan yang baik ${ }^{14}$.

Hanif menurut bahasa adalah lurus dan tidak condong pada sesuatu apapun. Sedangkan menurut istilahnya adalah selalu berpegang kepada kebenaran dan tak pernah meninggalkannya ${ }^{15}$. Terdapat persamaan antara hanif dan fitrah, yaitu selalu mengarah

${ }^{14}$ Budhy Munawwar Rachman, @fileCaknur Banyak Jalan Menuju Tuhan (Depok: Imania, 2013)

${ }^{15}$ Ridhoul Wahidi, Penafsiran Kata Hanif Dalam Al-Qur'an, Syahadah, Jurnal Ilmu AlQur'an dan Keislaman, Vol 1 No 1 (2013) Vol 1 No 1 (2013)

Al Qalam: Jurnal Ilmiah Keagamaan dan Kemasyarakatan

Vol. 14, No. 2, Juli-Desember 2020 
Andi Nurlaela, Su'udiyah Ningrum, Naan : Optimalisasi Nilai-Nilai Fitrah Dalam Mendekatkan Diri Kepada Allah

kepada kebenaran. Tidak heran jika manusia menggunakan fitrahnya secara maksimal, maka ia biasa disebut dengan orang yang hanif.

Bentuk fitrah dan kehanifan manusia tidak bisa dipisahkan satu sama lain. Karena sifat hanif mutlak menempel pada fitrah. Ibarat dalam kaidah nahwu, na'at dan man'ut, hanif merupakan sifat (na'at) sedangkan fitrah merupakan yang disifati (man'ut). Hanif sendiri merupakan kecenderungan dalam mencintai dan merindukan yang benar. Maka dengan adanya fitrah, manusia bersifat hanif, artinya secara alami ia merindukan dan selalu mencari yang baik dan benar. Bisa dikatakan sebuah kebenaran dan kebaikan bersifat alami atau natural, karena fitrah sendiri yang menunjukkan adanya kebenaran dan kebaikan.

Ketenangan akan diperoleh individu manakala ia mampu dan sadar akan kefitrahan dirinya sendiri. Keberadaannya diidentifikasi sebagai kekuatan yang tersimpan dengan rapi. Kekuatan yang bernama fitrah itu kemudian bisa dipancarkan dari dalam dirinya dan dialirkan ke dalam jiwa, pikiran, dan aliran darah. ${ }^{16}$ Sehingga ia akan bersifat dengan penuh kehanifan, artinya ia selalu berbuat dan mencari kebenaran dan kebaikan di setiap hembusan nafasnya, sehingga manfaat yang paling terpenting dalam sikap kehanifan manusia ialah akan terbukanya sedikit demi sedikit tabir antara dia dengan Allah. Karena fitrah tidak mungkin menjerumuskan manusia ke dalam jurang kesesatan. Maka ia akan selalu dekat dengan Allah dimanapun dan kapanpun jika ia mengoptimalkan pekerjaan fitrah dalam kehidupannya.

\section{Fitrah Bentuk Penyerahan Diri}

Untuk mencapai pertemuan dengan Allah, manusia harus rela mengorbankan dirinya dari kehidupan dunia. Disini fitrah merupakan bentuk dari pengorbanan diri manusia, karena tujuan fitrah ialah selalu mengarahkan manusia ke jalan Allah.

Sebagai khalifatul fil ardh, hendaknya manusia melakukan bentuk penyerahan diri kepada Allah. Karena penyerahan diri merupakan bentuk yang paling esensial dalam keberfungsiannya manusia sebagai khalifatul fil ardh. Adapun bentuk penyerahan diri kepada Allah antara lain, ialah penghambaan diri kepada Allah, kerendahan hati, penuh rasa syukur, dan terlepas dari belenggu keegoisan diri.

${ }^{16}$ Nasrudin, Iyus Herdiana, dan Nif'an Nazudi, Pengembangan Model Pendidikan Karakter Berdasarkan Sifat Fitrah Manusia, Jurnal Pendidikan Karakter, Tahun IV, Nomor 3, Oktober 2014

Al Qalam: Jurnal Ilmiah Keagamaan dan Kemasyarakatan Vol. 14, No. 2, Juli-Desember 2020 
Andi Nurlaela, Su'udiyah Ningrum, Naan : Optimalisasi Nilai-Nilai Fitrah Dalam Mendekatkan Diri Kepada Allah

Dasar penyerahan diri manusia bisa dilihat dari implementasi kelima rukun Islam. Yang pertama ialah dua kalimat syahadat. Pada kalimat dua syahadat ini, manusia sebenarnya sudah benar percaya bahwa Allah adalah Esa dan Muhammad adalah utusanNya. Karena dalam kalimat syahadat ini, manusia berkata bahwa ia "menyaksikan" dan bukan "kesaksian". Disini dapat kita analisis bahwa makna kaliamat "menyaksikan" ialah kalimat yang murni dari diri sendiri dan tanpa ada unsur paksaan ${ }^{17}$. Dalam kata "menyaksikan" ternyata sangatlah erat dengan fitrah yang terbentuk sebagai potensi penyerahan diri manusia. Ketika manusia sudah mengucapkan kalimat syahadat, berarti ia meyakini bahwa disegala apapun dan kapanpun ada Allah di dekatnya sehingga ia bisa menyaksikan-Nya. Salah satu bentuk manusia sadar bahwa Allah selalu berada di dekatnya, ia akan senantiasa berbuat kebaikan karena ia mengetahui bahwa ia sedang menyaksikan Allah, dan ia tidak ingin membuat Allah murka kepadanya karena ia memilih jalan yang salah. Disini potensi fitrah bisa optimal karena manusia senantiasa menuju kepada hakikatnya, yaitu menuju kebenaran.

Yang kedua ialah mendirikan shalat. Ini merupakan bentuk penguatan dari rukun Islam yang pertama, kalimat dua syahadat. Dalam hal ini secara sederhana bisa dikatakan sebagai konsekuensi syahadat. Artinya, ketika manusia sudah menyaksikan bahwa Allah itu ada, maka ia akan mengabdikan diri kepada-Nya. Adapun sesuai dengan firman Allah pada surat Al-Ankabut ayat 45: "Sesungguhnya shalat mencegah perbuatan keji dan mungkar." Tuhan tidak memperoleh manfaat ketika manusia mendirikan shalat, semakin manusia sering mendirikan shalat semakin bertambah keagungan Allah misalnya. Pada hakikatnya shalat merupakan salah satu perbuatan fitrah sebagai benteng dari perbuatan jahat. Di dalam shalat, manusia juga berikrar "Inna Shalatii wa nusuki wa mahyaya wa mamati lillahi robbil 'alamin” sebagaimana di dalam Al-Qur'an. Setidaknya kalimat tersebut memberi makna bahwa ketika manusia mendirikan shalat berarti ia sedang menyerahkan dirinya atau menagbdikan dirinya kepada Allah.

Selanjutnya ialah membayar zakat. Istilah zakat sendiri dalam surat Maryam ayat 13 bermakna suci, dan makna zakat dalam surat An-Nur ayat 21 berarti bersih dari keburukan dan kemungkaran. Dimana makna zakat ini relevan dengan makna fitrah itu sendiri, yakni menolak dari keburukan. Adapun penyebutan zakat dalam bulan Ramadhan

17 Kamba, Muhammad Nursamad, Kids Zaman Now Menemukan Kembali Islam (Tangerang selatan: Pustaka IIMaN, 2018)

Al Qalam: Jurnal Ilmiah Keagamaan dan Kemasyarakatan Vol. 14, No. 2, Juli-Desember 2020 
Andi Nurlaela, Su'udiyah Ningrum, Naan : Optimalisasi Nilai-Nilai Fitrah Dalam Mendekatkan Diri Kepada Allah

ialah zakat fitrah, ini berarti zakat merupakan bentuk penyucian jiwa dari segala hal yang kotor dan berfungsi sebagai tangga bagi fitrah dalam menuju puncaknya yaitu keridhaan Allah. Dalam kehidupan sehari-hari sering dikatakan bahwa sebagai umat muslim kita diharuskan melakukan zakat pada bulan Ramadhan, dan disunnahkan berzakat jika harta yang dimiliki sudah masuk dalam kewajiban berzakat. Namun Nursamad Kamba, pendiri jurusan Tasawwuf Psikoterapi UIN Sunan Gunung Djati Bandung mengaatakan bahwa berzakat sebenarnya ialah bentuk pembersihan diri melalui harta. Dalam hal ini tujuan utama ialalah penyerahan diri sehingga terbentuklah integritas pribadi. Dalam berzakat manusia membuktikan dan merealisasikan kerelaan untuk mengorbankan sebagian hartanya demi kepentingan khalayak umum. Zakat mengajarkan manusia untuk tidak terikat dengan keegoan demi memperoleh tujuan hidup, yakni Ridha Allah.

Kemudian rukun Islam yang keempat ialah berpuasa pada bulan Ramadhan. Berpuasa sendiri merupakan bentuk ritual dalam mendekatkan diri kepada Allah. dalam berpuasa manusia harus menahan godaan baik godaan lahir maupun godaan bathin. Godaan lahir yang timbul mungkin bisa ditahan oleh umat muslim itu sendiri, seperti makan dan minum. Namun manusia acap kali sukar dalam menahan godaan bathiniyah, disini godaan bathiniyah meliputi hasrat-hasrat duniawi, kecenderungan jiwa dan kecenderungan nafsu syahwat. Dalam berpuasa fitrah mengambil peran lebih banyak karena disini manusia harus mendengarkan bisikan fitrah agar ia berhasil mencapai keadaan berpuasa yang benar dan efektif serta tidak tersesat dalam godaan-godaan, terutama dalam godaan bathiniyah seperti menggunjing, memfitnah, berbohong, dan sebagainya.

Yang terakhir dalam rukun Islam ialah berhaji ke rumah Allah. berhaji merupakan bentuk penghambaan total kepada Sang Pencipta, karena menurut sejarah ritual haji berasal dari agama Ibrahim as. Antara lain ritual sai (bagaimana perjuangan Siti Hajar dalam mencari air untuk anaknya, Nabi Ismail), melontar jumroh (bentuk perlindungan Siti Hajar ketika digoda oleh setan), dan penyembelihan hewan (perintah Allah kepada Nabi Ibrahim untuk menyembelih anaknya sendiri, Nabi Ismail). Dalam berhaji umat manusia memakai pakaian ihram, dimana ia harus menanggalkan semua status duniawinya demi menuju kepada Allah. Berhaji ke rumah Allah adalah bentuk peniadaan diri, disini potensi fitrah sudah mencapai puncak atas karena ia sudah tidak lagi 
Andi Nurlaela, Su'udiyah Ningrum, Naan : Optimalisasi Nilai-Nilai Fitrah Dalam Mendekatkan Diri Kepada Allah

tunduk pada hasrat dan kecenderungan nafsu. Selyruh hidupnya hanyalah perpanjangan tangan dari Sang Ilahi Rabbi.

Dari kelima rukun Islam tersebut, tujuan dari ibadah itu bukanlah ibadah itu sendiri. Melainkan tujuannya ialah bagaimana membuat seseorang yang sukses dalam beribadah itu mempunyai sifat dan akhlak yang hanif, artinya pembentukan akhlak yang hanif diperoleh ketika umat manusia berhasil melakukan ibadah secara optimalitas. Disini lah letak pentingnya penggunaan fitrah dalam beribadah. Ketika manusia menggunakan fitrah dalam beribadah secara totalitas, maka ia akan mencapai kepuncakan dalam beribadah, artinya ibadah yang dilakukannya bersih dari perbuatan-perbuatan kejelekan dan kesesatan. Sehingga jalan menuju Allah pun bisa ia capai dengan hanya mengoptimalkan kerja fitrah dalam beribadah sehari-hari.

\section{KESIMPULAN}

Dari hasil penelusuran atas sumber-sumber teks dan hasil analisis, Penulis dapat menyimpulkan bahwa fitrah yang sudah dianugerahkan Allah kepada setiap manusia merupakan sebuah potensi yang luar biasa. Potensi ini dapat digali dan dikembangkan hingga menjadi suatu jalan untuk mendekatkan diri kepada Allah. Dengan fitrah kehidupan manusia akan selalu terarah menuju kebenaran hingga menuju puncak, yakni kebersatuan dengan Allah. Kebersatuan yang dimaksud di sini adalah pesan-pesan spiritual terinternalisasi dengan baik dan fitrah kemanusiaannya menjadi terjaga. Nilainilai kesucian, hanif, dan hal lainnya yang potensial, dapat dikelola dan diarahkan hanya untuk menuju-Nya melalui serangkaian usaha kebaikan yang diperintahkan dalam rukun Islam.

\section{DAFTAR PUSTAKA}

Farah, Naila and Cucum Novianti. "Fitrah Dan Perkembangan Jiwa Manusia Dalam Perspektif Al-Gazali”, YAQZHAN Volume 2, Nomor 2, Desember 2016.

Ismail, Syarifah. Tinjauan Filosofis Pengembangan Fitrah Manusia dalam Pendidikan Islam, Jurnal At-Ta'dib Vol. 8, No. 2, Desember 2013

Janah, Uul nur. Konsep Fitrah Manusia dan Relevansinya Terhadap Pengembangan Kreativitas Anak dalam Pendidikan Islam, Golden Age, Jurnal Ilmiah Tumbuh Kembang Anak Usia Dini, Vol 2 No 1 (2017)

Jhon, M Echols and Hasan Shadily. Kamus Indonesia-Inggris, Jakarta: Gramedia, 1994.

Al Qalam: Jurnal Ilmiah Keagamaan dan Kemasyarakatan

Vol. 14, No. 2, Juli-Desember 2020 
Andi Nurlaela, Su'udiyah Ningrum, Naan : Optimalisasi Nilai-Nilai Fitrah Dalam Mendekatkan Diri Kepada Allah

Kamba, Muhammad Nursamad. Kids Zaman Now Menemukan Kembali Islam, Tangerang selatan: Pustaka IIMaN, 2018.

Ma'luf,Louis. Al-Munjid Fi Al-Luhgah Wa Al-A'lam, Bairut-Libanon: Dar el-Mashreq, 1975.

Mappanganro, M. Mengembangkan Pendidikan Yang Menghargai Nilai Dan Fitrah Manusia, EDUKASI: Jurnal Penelitian Pendidikan Agama dan Keagamaan, VOLUME 1, NOMOR 4, OKTOBER 2003

Miftah, Muhammad. Quantum Learning Dan Fitrah Manusia Dalam Perspektif Pendidikan Islam, Insania, Vol. 25, No. 1, Januari - Juni 2020

Mualimin, Konsep Fitrah Manusia Dan Implikasinya Dalam Pendidikan Islam AlTadzkiyyah: Jurnal Pendidikan Islam, Vol 8, No 2 (2017)

Nasrudin, Iyus Herdiana, dan Nif'an Nazudi, Pengembangan Model Pendidikan Karakter Berdasarkan Sifat Fitrah Manusia, Jurnal Pendidikan Karakter, Tahun IV, Nomor 3, Oktober 2014

Pransiska, Toni. Konsepsi Fitrah Manusia Dalam Perspektif Islam Dan Implikasinya Dalam Pendidikan Islam Ontemporer, Jurnal Ilmiah Didaktika Media Ilmiah Pendidikan dan Pengajaran Vol 17, No 1 (2016)

Rachman, Budhy Munawwar. @fileCaknur Banyak Jalan Menuju Tuhan, Depok: Imania, 2013.

Rahayu, Muliya. Konsep Fitrah Manusia Dalam Al-Qur'an Dan Implikasinya Dalam Pendidikan Anak Usia Dini. JURNAL PUSAKA: Media Kajian dan Pemikiran Islam, Vol. 4 No. 1 (2016)

Siregar, Risdawati. Pengembangan Fitrah Manusia Melalui Konseling Islam, FITRAH:Jurnal Ilmu-ilmu Keislaman, Vol 1, No 1 (2015)

Suriadi, Fitrah Dalam Perspektif Al-Quran (Kajian Terhadap Ayat-Ayat Al-Quran), MUADDIB: Studi Kependidikan dan Keislaman Vol. 8 No. 2 (2018)

Wahidi, Ridhoul. Penafsiran Kata Hanif Dalam Al-Qur'an, Syahadah, Jurnal Ilmu AlQur'an dan Keislaman, Vol 1 No 1 (2013) Vol 1 No 1 (2013)

Al Qalam: Jurnal Ilmiah Keagamaan dan Kemasyarakatan

Vol. 14, No. 2, Juli-Desember 2020 